\title{
Above- and belowground fluxes of methane from boreal dwarf shrubs and Pinus sylvestris seedlings
}

\section{Halmeenmäki, Elisa}

2017-11

Halmeenmäki , E , Heinonsalo , J , Putkinen , A , Santalahti , M , Fritze , H \& Pihlatie , M 2017 , ' Above- and belowground fluxes of methane from boreal dwarf shrubs and Pinus sylvestris seedlings ' , Plant and Soil , vol. 420 , no. 1-2 , pp. 361-373 . https://doi.org/10.1007/s11104-017-3406-7

http://hdl.handle.net/10138/307478

https://doi.org/10.1007/s11104-017-3406-7

unspecified

acceptedVersion

Downloaded from Helda, University of Helsinki institutional repository.

This is an electronic reprint of the original article.

This reprint may differ from the original in pagination and typographic detail.

Please cite the original version. 

Above- and belowground fluxes of methane from boreal dwarf shrubs and Pinus sylvestris seedlings

E. Halmeenmäki, M. Pihlatie

4 Department of Forest Sciences, Viikki Plant Science Centre, P.O. Box 27, 00014 University of Helsinki, Finland

5 E. Halmeenmäki, A. Putkinen, M. Pihlatie

6 Department of Physics, P.O. Box 64, 00014 University of Helsinki, Finland

7 J. Heinonsalo, A. Putkinen, M. Santalahti

8 Department of Food and Environmental Sciences, Viikki Plant Science Centre, P.O. Box 66, 00014 University of Helsinki,

9 Finland

10 H. Fritze

11 Natural Resources Institute Finland, P.O. Box 12, 00791 Helsinki, Finland

13 Corresponding author: Elisa Halmeenmäki, elisa.halmeenmaki@helsinki.fi, phone: +358 504487104

\section{Keywords}

15 methane flux, methanogens, methanotrophs, boreal forest, plants

\section{Abstract}

17 Aims

The contribution of boreal forest plants to the methane $\left(\mathrm{CH}_{4}\right)$ cycle is still uncertain. We studied the above- and belowground $\mathrm{CH}_{4}$ fluxes of common boreal plants, and assessed the possible contribution of $\mathrm{CH}_{4}$ producing and oxidizing microbes (methanogens and methanotrophs, respectively) to the fluxes.

\section{Methods}

We measured the $\mathrm{CH}_{4}$ fluxes and the amounts of methanogens and methanotrophs in the above- and belowground parts of Vaccinium myrtillus, Vaccinium vitis-idaea, Calluna vulgaris and Pinus sylvestris seedlings and in non-planted soil in a microcosm experiment.

\section{Results}

The shoots of $C$. vulgaris and $P$. sylvestris showed on average emissions of $\mathrm{CH}_{4}$, while the shoots of the Vaccinium species indicated small $\mathrm{CH}_{4}$ uptake. All the root-soil-compartments consumed $\mathrm{CH}_{4}$, however, the non-rooted soils showed on average small $\mathrm{CH}_{4}$ emission. We found methanotrophs from all the rooted and non-rooted soils. Methanogens were not detected in the plant or soil materials.

\section{Conclusions}

31 The presence of plant roots seem to increase the amount of methanotrophs and thus $\mathrm{CH}_{4}$ uptake in the soil. The $\mathrm{CH}_{4}$ emissions from the shoots of $C$. vulgaris and $P$. sylvestris demonstrate that the plants have an 
Atmospheric methane $\left(\mathrm{CH}_{4}\right)$ mixing ratio has increased 1.5-fold since pre-industrial times, and continues to rise with increasing rate (Hartmann et al. 2013). Among land ecosystems the largest known $\mathrm{CH}_{4}$ sources include anaerobic environments such as natural wetlands and rice paddies, which have an abundance of $\mathrm{CH}_{4}$ producing archaea (methanogens). Aerated upland soils are the largest sink of $\mathrm{CH}_{4}$ in the biosphere due to $\mathrm{CH}_{4}$ oxidizing bacteria (methanotrophs) in the soil (Kirschke et al. 2013).

Vegetation is a potentially important factor in the ecosystem-atmosphere $\mathrm{CH}_{4}$ exchange, and its contribution to the global $\mathrm{CH}_{4}$ budget is the most uncertain component among all natural $\mathrm{CH}_{4}$ sources (Carmichael et al. 2014). The most common method to measure soil greenhouse gas fluxes is the chamber method (Livingston and Hutchinson 1995), which does not allow to separate the contributions of the plants or the soil, or the belowand aboveground parts of the system, to the flux. Furthermore, the soil chamber method does not include trees, which are recently discovered to play a significant role in the ecosystem $\mathrm{CH}_{4}$ exchange (Rusch and Rennenberg 1998; Pangala et al. 2015; Machacova et al. 2016).

The net $\mathrm{CH}_{4}$ flux between ecosystem and the atmosphere depends on the $\mathrm{CH}_{4}$ production, consumption and exchange rates. In addition to methanotrophs, upland soils may also contain methanogens (Angel et al. 2012), moisture increases enough (Sjögersten and Wookey 2002; Matson et al. 2009; Shoemaker et al. 2014). Active methanogens have also been detected on the surface of roots of Scots pine (Pinus sylvestris) and other common boreal forest trees (Bomberg et al. 2011). Furthermore, during wet autumns the $\mathrm{CH}_{4}$ emissions from upland boreal forest soils can significantly contribute to the ecosystem scale $\mathrm{CH}_{4}$ balance (Lohila et al. 2016).

The transport of methanogen-produced $\mathrm{CH}_{4}$ from soil to the atmosphere through aerenchyma tissue in plants is a well-documented process among wetland species such as Carex spp. (Whiting and Chanton 1992; Joabsson et al. 1999; Ding et al. 2005) and Menyanthes trifoliata (Macdonald et al. 1998), as well as in rice (Oryza sativa) (Cicerone and Shetter 1981). Riparian deciduous trees (Fraxinus latifolia, Populus trichocarpa, and Salix fluviatilis) (Rice et al. 2010) and wetland trees (Alnus glutinosa L., Fraxinus mandshurica var. japonica, and Betula pubescens) (Rusch and Rennenberg 1998; Terazawa et al. 2007; Gauci et al. 2010; Pangala et al. 2015) have also been discovered to have a capacity for $\mathrm{CH}_{4}$ transport. Recently (Maier et al. 2017a) hypothesized that beeches (Fagus sylvatica) growing at upland site can also transport $\mathrm{CH}_{4}$ via roots. In the boreal region, mature $P$. sylvestris trees emitted $\mathrm{CH}_{4}$ from both stems and shoots, the emissions from the shoots being an order of magnitude larger than those from the stems (Machacova et al. 2016). Thus, not only herbaceous but also woody species are able to transport $\mathrm{CH}_{4}$ from soil to the atmosphere.

Methanogens living in the plant material have also been suggested as the origin of the $\mathrm{CH}_{4}$ emissions from plants. Emissions of $\mathrm{CH}_{4}$ have been measured from stem samples of $P$. sylvestris and silver birch (Betula pendula), in a laboratory experiment (Mukhin and Voronin 2011). Furthermore, high $\mathrm{CH}_{4}$ concentrations have been detected inside the stems of standing trees of both deciduous (Quercus rubra, Betula alleghaniensis, Betula lenta, and Acer rubrum) and conifer species (Pinus strobus and Tsuga canadensis) (Covey et al. 2012). In addition, during the past decade there have been studies demonstrating that terrestrial plants can also emit $\mathrm{CH}_{4}$ from living plant material under aerobic conditions (Keppler et al. 2006; Vigano et al. 2008; Bruhn et al. 2009; Bloom et al. 2010). Leaf $\mathrm{CH}_{4}$ emissions from terrestrial plants under aerobic conditions have been demonstrated to be induced by ultraviolet (UV) radiation (Vigano et al. 2008; Bruhn et al. 2009). In contrast, Sundqvist et al. (2012) found $\mathrm{CH}_{4}$ uptake by the shoots of common boreal trees in the field, including $P$. sylvestris, which is contrary not only to the last-mentioned results of the laboratory experiments, but also to the field measurements by Machacova et al. (2016). This underlines the need for further experiments on the plant $\mathrm{CH}_{4}$ fluxes. 
Even though estimates of the contribution of the plants to the ecosystem scale $\mathrm{CH}_{4}$ flux have been made e.g. for tropical and temperate zones (Pangala et al. 2013; Pangala et al. 2015), the process understanding of $\mathrm{CH}_{4}$ flux from vegetation is quite limited, and thus vegetation is not yet included in the global $\mathrm{CH}_{4}$ budget. The production mechanisms behind the $\mathrm{CH}_{4}$ emissions from plants are not fully understood, and the partitioning of $\mathrm{CH}_{4}$ fluxes between above and belowground parts of the vegetation is yet unknown. In boreal forest ecosystems the ground vegetation, consisting mainly of dwarf shrubs and mosses, contributes substantially (13\%) to the ecosystem gross primary production (GPP) (Kolari et al. 2006; Kulmala et al. 2011). Based on this we hypothesize that ground vegetation may also contribute to the $\mathrm{CH}_{4}$ exchange in boreal forests.

In this study, we measured $\mathrm{CH}_{4}$ flux from seedlings of three dwarf shrub species (Vaccinium myrtillus L., Vaccinium vitis-idaea L., and Calluna vulgaris L.) and one tree species ( $P$. sylvestris L.) representative to boreal upland forests. The plants were grown in microcosms under controlled laboratory conditions. The aim and uniqueness of this set up was to investigate the roles of the aboveground parts and the belowground root-soilsystems of the seedlings on $\mathrm{CH}_{4}$ fluxes, and to quantify and assess the role of methanogens and methanotrophs in the $\mathrm{CH}_{4}$ exchange of the studied plants and the soil. Additionally, we compared the flux data to soil chemistry and enzyme activities (Adamczyk et al. 2016), and the number of bacteria in the soil and roots (Timonen et al. 2016), both of which have been analysed within the same microcosm experiment.

\section{Materials and Methods}

\section{Experimental design}

There were 8 seedlings of each of the four species (V. myrtillus, V. vitis-idaea, C. vulgaris, and $P$. sylvestris) in this experiment, one seedling per microcosm. In addition, there were 11 soil microcosms without a plant, which were treated the same way as the planted ones throughout the experiment. The plants were grown from seeds under laboratory conditions and replanted into the microcosms as small seedlings. The microcosms consist of a thin chamber enclosing the soil and the roots, and of a separate transparent chamber that can be attached to the shoot of a plant (for complete description of the microcosms see Pumpanen et al. (2009)). The total volumes of the soil and the shoot compartments are $348 \mathrm{~cm}^{3}$ and $675 \mathrm{~cm}^{3}$, respectively. The microcosms are not permeable to UV radiation.

The humus layer of the soil and the berries of the Vaccinium species were collected in autumn from a Scots pine dominated forest near the SMEAR II station in Hyytiälä, southern Finland (61 ${ }^{\circ} 51^{\prime} \mathrm{N}, 24^{\circ} 17^{\prime} \mathrm{E}, 181 \mathrm{~m}$ a.s.I.), where the soil type is haplic podzol (FAO/UNESCO 1990). The field layer is dominated by V. myrtillus and $V$. vitis-idaea, and also C. vulgaris is common in the area (Kolari et al. 2006). The soil was homogenized and sieved before using for the construction of germination pots and the microcosms. The seeds of $P$. sylvestris were from a seed lot (M29-92-0059, Natural Resources Institute Finland), and the seeds of the Vaccinium species were separated from the berries. All the seeds were surface sterilized before germination (for details see Adamczyk et al. (2016)). C. vulgaris seedlings were germinated naturally from the sieved humus. At the time of constructing the microcosms, ca. $178 \mathrm{~cm}^{3}$ of moist homogenized humus soil was inserted into each soil compartment.

Before the $\mathrm{CH}_{4}$ flux measurements, the seedlings had been in stabile growth conditions for ca. 11 months, and they had grown to a height of ca. $10 \mathrm{~cm}$ (for details see Adamczyk et al. (2016)). The growth room was equipped with daylight spectrum lamps, which followed a diurnal rhythm of 18 hours daytime and 6 hours night-time. The daytime photosynthetic photon flux density (PPFD) was $160-220 \mu \mathrm{mol} \mathrm{m}^{-2} \mathrm{~s}^{-1}$ (LI-190R Quantum Sensor with LI-COR Biosciences LI-250A Light Meter, LI-COR Biosciences, Nebraska, USA) and with reverse osmosis water to $100 \%$ water holding capacity. The last irrigation was done approximately 24 
hours before the flux measurements. The plants' exposure to daylight lamps was ceased ca. 12 hours before the measurements.

\section{Methane flux measurements}

For the flux measurements the soil and the shoot compartments of the microcosms were separately but simultaneously closed airtight, and three manual gas samples of $20 \mathrm{ml}$ were taken from the air space of each compartment at time $1 \mathrm{~min}, 30 \mathrm{~min}$ and $60 \mathrm{~min}$ after closure with a plastic syringe (BD Plastipak ${ }^{\mathrm{TM}}$, Becton, Dickinson and Company, New Jersey, USA). At the same time with each sampling the same volume (20 ml) of replacement air (compressed air; $2.0 \mathrm{ppm} \mathrm{CH}_{4}$ ) was injected into the microcosm in order to maintain the air volume and to avoid pressure changes. Note that the non-planted soil microcosms did not have an aboveground cuvette. The temperature on top of the microcosms was between $16-24.5^{\circ} \mathrm{C}$ during the measurements (median $19.5^{\circ} \mathrm{C}$ ). The sampling was performed in regular indoor light conditions with PPFD ranging between $10-19 \mu \mathrm{mol} \mathrm{m}{ }^{-2} \mathrm{~s}^{-1}$ and without UV radiation.

Gas samples were injected into glass vials (12 ml, Labco Exetainer ${ }^{\circledR}$, Labco Limited, Wales, UK) and analysed with a gas chromatograph (7890A, Agilent Technologies, California, USA) equipped with a flame ionization detector (FID) (for details of the instrument see Pihlatie et al. 2013). The method quantification limit (MQL) of the analyser was calculated according to Corley (2003), and it was $0.10 \mathrm{ppm}$ for $\mathrm{CH}_{4}$.

The $\mathrm{CH}_{4}$ flux was calculated using the least squares method to calculate the line of best fit for the concentration change in time. The belowground compartment volume used for the flux calculation was quantified as the air space around and within the soil. The porosity was calculated by using the particle density of organic matter of a pine forest (Redding et al. 2005). The soil air within the pores was determined by subtracting the volume of water, which was calculated from the soil fresh weight (FW) and dry weight (DW) and the density of water (1 g $\mathrm{cm}^{-3}$ ). The average air volume of the belowground compartments was $229 \mathrm{~cm}^{3}$. The $\mathrm{CH}_{4}$ flux was further divided by the total DW of the below- or aboveground material. The flux data was further processed by setting the flux values with NRMSE (Normalized Root Mean Square Error) value larger than 0.35 and $R^{2}$ value smaller than 0.5 to zero. This was based on an assumption that very small fluxes with poor goodness of fit, and measurements with highly fluctuating $\mathrm{CH}_{4}$ concentrations can be assumed as zero fluxes, which represented $40 \%$ of the data. From the fluxes that met the quality criteria, $56 \%$ were above the MQL. The MQL is rather conservative, and thus also fluxes smaller than MQL are reported in the results if the data quality passes the NRMSE and $\mathrm{R}^{2}$ criteria. The net fluxes of the plant-soil systems were calculated by adding the belowground flux to the aboveground flux (as nmol $\mathrm{CH}_{4} \mathrm{~h}^{-1}$ ), and dividing this flux by the total DW of soil and plant material.

After the $\mathrm{CH}_{4}$ flux measurements, the microcosms were dismantled. For the plants, the shoots were cut off, and the roots were carefully separated from the soil. Samples of shoots, roots, and soil were freeze-dried, and thereafter stored at $-20^{\circ} \mathrm{C}$. The dried shoots and roots were weighted separately. The FW and DW of the nonrooted soils were determined, and to quantify the total soil weight of the rooted soils, the mean of the nonrooted soil DWs was used.

\section{Microbiological analyses}

Total DNA was extracted from the roots, stems and leaves of all the plants, as well as the soil by weighing 0.05 $\mathrm{g}$ (FW) of fresh soil, $0.25 \mathrm{~g}$ (FW) of fresh roots and $0.025 \mathrm{~g}$ (DW) of dry lyophilized and ground shoot material (stem and leaves). Soil samples were extracted with NucleoSpin ${ }^{\circledR}$ Soil genomic DNA extraction kit (MachereyNagel, Düren, Germany) and roots were extracted manually from homogenized sample material with hot-CTAB method at $+65^{\circ} \mathrm{C}$ as in (Timonen et al. 2016). DNA from soil and roots were further purified with PowerClean ${ }^{\circ}$ DNA Clean-up kit (Mo Bio Laboratories Inc, USA) according to manufacturer's instructions. Shoot samples were extracted using NucleoSpin ${ }^{\circledR}$ Plant genomic DNA extraction kit (Macherey-Nagel, Düren, Germany) according to manufacturer's instructions without further purification. 
To detect and quantify the methanogenic archaea, quantitative PCR (qPCR) with primers mlas/mcrA-rev (Steinberg and Regan 2008) targeting the mcrA gene coding for the $\alpha$-subunit of the methyl-coenzyme $M$ reductase was applied. Analysis was done in $20 \mu \mathrm{l}$ reaction volume with $1 \times$ SsoAdvanced ${ }^{\mathrm{TM}}$ Universal SYBR ${ }^{\circledR}$ Green Supermix (Bio-Rad Laboratories Inc., Hercules, CA, USA), $500 \mathrm{~nm}$ of each primer and 1-10 ng of the template DNA ( $1 \mu \mathrm{l}$ of undiluted or 1:10 diluted DNA extract from root, shoot or soil samples). Amplification was performed with CFX96 Touch $^{\text {TM }}$ Real-Time PCR detection system (Bio-Rad Laboratories Inc., Hercules, CA, USA) with the following cycling parameters: $98^{\circ} \mathrm{C}$ for $3 \mathrm{~min}, 45 \mathrm{cycles}$ of $98^{\circ} \mathrm{C}$ for $15 \mathrm{~s}$ and $60^{\circ} \mathrm{C}$ for $1 \mathrm{~min}$. To verify the specificity of the products, melt curve analysis was performed by increasing the temperature from 65 ${ }^{\circ} \mathrm{C}$ to $95{ }^{\circ} \mathrm{C}$ with $0.5^{\circ} \mathrm{C}$ increment per every $5 \mathrm{~s}$. All possibly positive samples were also run in $1.0 \%$ agarose gel (Bioline, London, UK), stained with $0.3 \%(\mathrm{~W} / \mathrm{w})$ ethidium bromide (Sigma-Aldrich, Steinheim, Germany) and visualized under UV-light. Negative PCR controls remained free of PCR amplicons. Standard curve was based on a 10-fold dilution series of a target PCR product cloned into a TOPO pCR2.1 plasmid (Thermo Fisher Scientific, Waltham, MA, USA). Standards and samples were run in duplicate in each run. Efficiencies of the qPCR amplifications were between $96.5 \%$ and $100.5 \%$ in the individual mcrA runs. DNA concentrations were measured with Qubit 2.0 Fluorometer with dsDNA HS Assay Kit (Thermo Fisher Scientific).

Methanotrophs were analysed with primers A189f/A650r (Holmes et al. 1995; Bourne et al. 2001) targeting the pmoA gene coding for the $\alpha$-subunit of particulate methane monooxygenase. Reverse primer mb661r (Costello and Lidstrom 1999) was also tested but no proper products were amplified. Protocol for the $p m o A$ was analogous to $m c r A$ except for the annealing/extension temperature being $59^{\circ} \mathrm{C}$, lower primer amount $(300 \mathrm{nM}$ each), addition of $5 \mu \mathrm{g}$ of bovine serum albumin (Thermo Fisher Scientific, Waltham, MA, USA) to the reaction mix and running the standard dilution series in triplicate. Test runs with shoot derived DNA extracts (individual and pooled) did not provide correct $p m o A$ PCR product and thus shoots were not thoroughly analysed with pmoA qPCR. Efficiencies of the qPCR amplifications were between $88 \%$ and $95.3 \%$ in the individual pmoA runs.

Inhibition of the samples was tested with spiking the standard with template DNA as in Goebel et al. (2010). Inhibition levels were calculated for each plant/sample type and taken into account when calculating the gene copy numbers (on average $5 \%$ for soil, $0.7 \%$ for roots and $3 \%$ for shoots).

Based on all the individual qPCR runs, the smallest reliably quantified standard was $10^{1}$ gene copies reaction ${ }^{-1}$ (both assays) which was thus considered the limit of quantification. In our samples, this value equals on average $6.7 \times 10^{5}$ gene copies $\mathrm{g}^{-1}(\mathrm{DW})$ for soil, $5.2 \times 10^{4}$ gene copies $\mathrm{g}^{-1}(\mathrm{DW})$ for roots and $4.0 \times 10^{4}$ gene copies $\mathrm{g}^{-1}$ (DW) for shoots, respectively. If the quantification limit was not reached, genes were still considered detected if the PCR product was visible and the size matched the standard product when visualized in $1 \%$ agarose gel.

\section{Statistical analyses}

The differences between the mean values of the fluxes from different compartments were tested by analysis of variance (ANOVA), and Tukey-Kramer test was applied as a post hoc test for multiple comparison. The differences between the numbers of methanotrophs was tested with Welch ANOVA due to unequal variances, and Games-Howell post hoc test was used. For both the fluxes and methanotrophs, the differences from zero were tested with one sample t-test. Two-sample t-test was performed to test the differences between two groups, except when the groups had unequal variances, Welch t-test was applied.

The Spearman's correlation was used to study the relationships between the methanotrophs and the $\mathrm{CH}_{4}$ fluxes. In addition, the $\mathrm{CH}_{4}$ fluxes of this study were compared to other variables analysed from samples from the same microcosms: soil extracellular enzyme activity, soil organic matter characteristics, and the number of enchytraied worms in the soil (Adamczyk et al. 2016), and to the number of bacterial 16S rRNA gene copies 
209 (total amount of bacteria) within the soil and the roots (Timonen et al. 2016). The relationships were studied 210 with the Spearman's correlation. To assess the effect of general enzyme activity of the soils, we calculated a 211 sum of all the enzyme activities measured by Adamczyk et al. (2016). The correlation analyses were performed 212 separately for the above- and belowground data, as well as for the different plant species and soil.

213 All the statistical analyses were assessed at a significance level of $p<0.05$. The statistical analyses were 214 performed with Matlab (version R2014a, MathWorks, Massachusetts, USA), except for Welch ANOVA and 215 Welch t-test, which were done by using SPSS (version 22, IBM SPSS Statistics, New York, USA).

\section{Results}

\section{Methane fluxes}

218 The average $\mathrm{CH}_{4}$ fluxes from belowground compartments of all the studied plants showed small $\mathrm{CH}_{4}$ uptake, 219 while the bare soil emitted small amounts of $\mathrm{CH}_{4}$ (Table 1). The fluxes from the rooted soils were between $220-2.8-1.7 \mathrm{nmol} \mathrm{CH}_{4} \mathrm{~h}^{-1}$ or $-0.081-0.049 \mathrm{nmol} \mathrm{CH}_{4} \mathrm{~h}^{-1} \mathrm{~g}^{-1}$ (DW), and from the non-rooted soils between -1.1-3.5 $221 \mathrm{nmol} \mathrm{CH}_{4} \mathrm{~h}^{-1}$ or $-0.039-0.12 \mathrm{nmol} \mathrm{CH}_{4} \mathrm{~h}^{-1} \mathrm{~g}^{-1}$. There was a statistically significant $(p<0.01)$ difference between 222 the mean $\mathrm{CH}_{4}$ fluxes of the bare soil and the soil with $V$. vitis-idaea roots. Moreover, when all the rooted soils 223 were pooled together and compared to the non-rooted soil, there was a difference between the mean fluxes $224(p<0.01)$. Additionally, there was a significant difference between the belowground fluxes of $V$. vitis-idaea and $225 V$. myrtillus, as well as between $V$. vitis-idaea and $C$. vulgaris $(p<0.05)$. The average aboveground fluxes of $C$. 226 vulgaris and $P$. sylvestris indicated small $\mathrm{CH}_{4}$ emissions, while the mean flux of the Vaccinium species were 227 slightly negative (Table 1). The $\mathrm{CH}_{4}$ fluxes from the shoot compartments were ranging from -6.6 to $7.3 \mathrm{nmol}$ $228 \mathrm{CH}_{4} \mathrm{~h}^{-1}$ or $-3.2-3.3 \mathrm{nmol} \mathrm{CH} \mathrm{h}^{-1} \mathrm{~g}^{-1}$. The aboveground mean flux was significantly higher than the belowground 229 mean flux when all the species were pooled together $(p<0.05)$. 
Table 1. The arithmetic means \pm standard errors of the means, medians, minimum and maximum of the $\mathrm{CH}_{4}$ fluxes in $\mathrm{nmol} \mathrm{h}{ }^{-1}$ and $\mathrm{nmol} \mathrm{h}^{-1} \mathrm{~g}^{-1}$ (DW of the total plant and/or soil mass), and the number of microcosms in each group. The statistics of the fluxes are given for the whole plant-soil system (net flux), and separately for the belowground (belowg.) and aboveground (aboveg.) compartments.

\begin{tabular}{|c|c|c|c|c|c|c|c|c|c|c|c|}
\hline & \multicolumn{5}{|c|}{$\mathrm{CH}_{4}$ Flux $\left(\mathrm{nmol} \mathrm{h}^{-1}\right)$} & \multicolumn{5}{|c|}{$\mathrm{CH}_{4}$ Flux $\left(\mathrm{nmol} \mathrm{h}^{-1} \mathrm{~g}^{-1}\right)$} & \\
\hline & Mean & $\pm \mathrm{SE}$ & Median & Min & Max & Mean & $\pm \mathrm{SE}$ & Median & Min & Max & $\mathrm{n}$ \\
\hline $\begin{array}{l}\text { V. myrtillus } \\
\text { (net flux) }\end{array}$ & -0.14 & \pm 1.0 & -0.45 & -3.9 & 3.9 & -0.0029 & \pm 0.028 & -0.012 & -0.11 & 0.11 & 8 \\
\hline Belowg. & $-0.025^{a}$ & \pm 0.32 & 0 & -1.2 & 1.7 & $-0.0070^{a}$ & \pm 0.0091 & 0 & -0.035 & 0.049 & 8 \\
\hline Aboveg. & -0.16 & \pm 0.93 & 0 & -3.9 & 3.9 & -0.045 & \pm 0.61 & 0 & -3.2 & 3.0 & 8 \\
\hline $\begin{array}{l}\text { V. vitis-idaea } \\
\text { (net flux) }\end{array}$ & -1.7 & \pm 0.46 & -2.1 & -3.5 & 0.044 & -0.044 & \pm 0.012 & -0.052 & -0.086 & 0.0012 & 8 \\
\hline Belowg. & $-1.2^{b^{*}}$ & \pm 0.41 & -1.2 & -2.8 & 0 & $-0.035 b^{*}$ & \pm 0.012 & -0.036 & -0.081 & 0 & 8 \\
\hline Aboveg. & -0.46 & \pm 0.55 & 0 & -3.5 & 1.7 & -0.028 & \pm 0.15 & 0 & -0.71 & 0.83 & 8 \\
\hline $\begin{array}{l}\text { C. vulgaris } \\
\text { (net flux) }\end{array}$ & 3.2 & \pm 1.4 & 3.8 & -2.8 & 7.7 & 0.084 & \pm 0.036 & 0.10 & -0.078 & 0.20 & 8 \\
\hline Belowg. & $-0.051^{a}$ & \pm 0.24 & 0 & -1.5 & 0.75 & $-0.0015^{a}$ & \pm 0.0071 & 0 & -0.044 & 0.022 & 8 \\
\hline Aboveg. & 3.2 & \pm 1.5 & 4.2 & -3.6 & 7.3 & 1.1 & \pm 0.64 & 1.2 & -2.0 & 3.2 & 8 \\
\hline $\begin{array}{l}\text { P. sylvestris } \\
\text { (net flux) }\end{array}$ & 1.2 & \pm 1.5 & 0.78 & -7.2 & 6.3 & 0.032 & \pm 0.041 & 0.021 & -0.20 & 0.17 & 8 \\
\hline Belowg. & $-0.35^{a b}$ & \pm 0.16 & -0.19 & -1.2 & 0 & $-0.010^{a b}$ & \pm 0.0045 & -0.0054 & -0.035 & 0 & 8 \\
\hline Aboveg. & 1.6 & \pm 1.5 & 0.97 & -6.6 & 6.7 & 0.54 & \pm 0.61 & 0.41 & -2.7 & 3.3 & 8 \\
\hline Non-rooted Soil & $0.59^{a}$ & \pm 0.37 & 0.44 & -1.1 & 3.5 & $0.019^{a}$ & \pm 0.013 & 0.011 & -0.039 & 0.12 & 11 \\
\hline
\end{tabular}

${ }^{a b}$ Means of the belowground fluxes denoted by a different letter are significantly different $(p<0.05)$

${ }^{*}$ Significant difference from zero $(p<0.05)$.

The net fluxes of the seedlings of $C$. vulgaris and $P$. sylvestris indicated on average $\mathrm{CH}_{4}$ emissions (Table 1.), since the $\mathrm{CH}_{4}$ uptake of the rooted soils of these two species were relatively small compared to the shoot emissions. The mean net fluxes of the Vaccinium species showed $\mathrm{CH}_{4}$ uptake (Table 1.), while the net uptake of $V$. vitis-idaea was larger than the net uptake of $V$. myrtillus due to significant difference between their average belowground fluxes.

242 In addition to the fluxes, we examined the $\mathrm{CH}_{4}$ mixing ratios in the last samples taken after one hour closure. We compared the $\mathrm{CH}_{4}$ content between the above- and belowground compartments, and between the rooted and non-rooted soils. The measured mixing ratios of $\mathrm{CH}_{4}$ from the shoot compartments were between 2.0-2.3 $\mathrm{ppm}$, while the root compartment mixing ratios were between 1.6-2.1 ppm. The mixing ratios from the nonrooted soil were at the same level as those from the shoots, ranging between $2.0-2.2 \mathrm{ppm}$. The mean $\mathrm{CH}_{4}$ mixing ratios in the shoot compartments were significantly higher than those in the root compartments for all the species ( $p<0.01$ ) (Fig. 1). Furthermore, the mean $\mathrm{CH}_{4}$ mixing ratios of the root compartments of all the plant species were significantly lower than the mean of the soil compartments $(p<0.01)$. 
Fig. 1 The mean $\mathrm{CH}_{4}$ mixing ratios (ppm) in the $3^{\text {rd }}$ gas samples after one hour closure from the above- and belowground compartments of different plants and soil. The black circles and grey triangles are the mean values, and error bars are standard error of the mean (SEM). The statistically significant differences $(p<0.01)$ between the compartments are indicated by different letters. The grey line is the mean of the background $\mathrm{CH}_{4}$ level before the measurements, and the shaded area shows the standard error of the mean (SEM)

\section{Methanotrophs and methanogens}

Methanotrophs were detected in quantifiable amounts in the non-rooted soils as well as in the rooted soils of all the studied species (Fig. 2). The rooted soils of all the studied plants contained more methanotrophs than the non-rooted soil, and the difference was statistically significant for V. myrtillus, V. vitis-idaea, and C. vulgaris $(p<0.05)$ (Fig. 2). V. vitis-idaea and C. vulgaris had the highest amounts of methanotrophs. There was also a difference between the rooted and non-rooted soils when all the species were pooled together $(p<0.001)$. Methanotrophs were also detected in the roots of all plants but their $p m o A$ gene copy numbers were below the quantification limit $\left(<10^{1}\right.$ copies reaction $\left.{ }^{-1}\right)$. No valid $p m o A$ products were amplified from any of the shoot samples.

Methanogens were below the detection limit in all of the samples.

Fig. 2 Methanotroph related $p m o A$ gene copies in soil (gene copies $\mathrm{g}^{-1}$ of soil DW), based on primer pair A189f/A650r. The black circle is the mean, and the error bars represent the standard error of the mean. The letters indicate statistically significant differences and asterisks show significant differences from zero $(p<0.05)$

\section{Effects of biotic and abiotic variables on the $\mathrm{CH}_{4}$ fluxes}

All the rooted soils pooled, there were negative correlations between the $\mathrm{CH}_{4}$ fluxes and the total amount of bacteria in the roots (measured by Timonen et al. (2016)) $\left(r_{s}(21)=-0.43, p<0.05\right)$, between the fluxes and the soil recalcitrant nitrogen $(\mathrm{N})$ pool $\left(r_{s}(17)=-0.55, p<0.05\right)$, and between the fluxes and the soil $\mathrm{NH}_{4}$ concentration $\left(r_{s}(30)=-0.52, p<0.01\right)$ (all the soil chemical properties were measured by Adamczyk et al. (2016)) (Online Resource 1). A strong negative correlation was found between the $P$. sylvestris belowground $\mathrm{CH}_{4}$ fluxes and the concentration of total water-soluble phenolic compounds in the soil $\left(r_{s}(6)=-0.84, p<0.05\right)$ (Online Resource 1). In addition, there was a strong, although barely non-significant, negative correlation between the $P$. sylvestris belowground flux and the amount of bacteria in the soil $\left(r_{s}(4)=-0.88, p=0.050\right)$ (Online Resource 1). A negative correlation denotes that as the explanatory variable increases, the $\mathrm{CH}_{4}$ flux decreases towards more negative values i.e. the $\mathrm{CH}_{4}$ uptake increases, and a positive correlation stands for the $\mathrm{CH}_{4}$ flux increasing towards emission with increasing explanatory variable.

When all the aboveground fluxes were pooled, there were significant positive correlations between the shoot $\mathrm{CH}_{4}$ fluxes and the total water-soluble phenolic compounds in the soil $\left(r_{s}(30)=0.45, p<0.01\right)$, and between the fluxes and the soil condensed tannins $\left(r_{s}(30)=0.40, p<0.05\right)$ (Online Resource 1 ). When the shoot $\mathrm{CH}_{4}$ fluxes were explored one species at a time, there was a strong positive correlation between the shoot fluxes of V.vitis-idaea and the total $\mathrm{N}$ content in soil $\left(r_{s}(6)=0.85, p<0.05\right)($ Online Resource 1$)$.

\section{Discussion}

The design of this experiment provided a unique opportunity to observe the differences of the $\mathrm{CH}_{4}$ fluxes between the above- and belowground parts of the plant-soil systems, and study separately plant species that normally grow intermingled in the same habitat. In this study the observed fluxes were also connected with the abundances of the $\mathrm{CH}_{4}$ consuming and the producing microbes. We discovered that the aboveground parts of C. vulgaris and $P$. sylvestris were on average sources of $\mathrm{CH}_{4}$, while the shoots of the Vaccinium species showed on average small uptake. The rooted soils of all the studied species indicated $\mathrm{CH}_{4}$ uptake, as expected based on 
general understanding of forest soils (Kirschke et al. 2013). Interestingly, as the soil without a plant showed small $\mathrm{CH}_{4}$ emission, our data highlights that active plant root systems strongly promote methanotrophy in forest soils. These findings were supported by the differences in the $\mathrm{CH}_{4}$ mixing ratios between the above- and belowground compartments, and the rooted and non-rooted soils. Based on current understanding the shoot emissions may result from two different mechanisms: 1 ) transport of soil-derived $\mathrm{CH}_{4}$ by the plants (Rusch and Rennenberg 1998; Rice et al. 2010; Pangala et al. 2015), or 2) $\mathrm{CH}_{4}$ production within the plants, which can be either anaerobic and microbial (Mukhin and Voronin 2011), aerobic and microbial (Lenhart et al. 2015) or aerobic and non-microbial (Keppler et al. 2006; Vigano et al. 2008; Bruhn et al. 2009; Bloom et al. 2010).

As mcrA gene copies, belonging to methanogenic archaea, were below the detection limit in all the plant and soil samples in this study, our results suggest that the $\mathrm{CH}_{4}$ emitted from the plant shoots was not produced by methanogens. However, the positive $\mathrm{CH}_{4}$ flux together with the relatively high $\mathrm{CH}_{4}$ mixing ratio detected in the non-rooted soils suggest that $\mathrm{CH}_{4}$ production did indeed occur in the soil. In this case, some of the $\mathrm{CH}_{4}$ may have been transported by the plant from the soil to the aboveground air space, which would also in part explain the difference between the rooted and non-rooted soil $\mathrm{CH}_{4}$ fluxes. While an aerenchyma formation within ericoid shrubs is yet unknown, some flood-tolerant Pinus species have been discovered to form an aerenchyma when grown in hydroponic solution (Topa and McLeod 1986). Although dry forest soils are not in general preferable environments for the methanogens, previous research has observed presumably methanogen-derived $\mathrm{CH}_{4}$ production in oxic soils (Andersen et al. 1998; von Fischer and Hedin 2002) and revealed their resistance to long periods of desiccation (Angel et al. 2011). Moreover, as PCR is based on primers designed based on already known DNA sequences, it is possible that so far unrecognised methanogens were left undetected. Thus, we cannot fully rule out the presence of an undetectably small, soil dwelling methanogen population, which theoretically could produce some $\mathrm{CH}_{4}$, which was then emitted from the nonrooted soil and the shoots of $V$. vitis-idaea, $C$. vulgaris, and $P$. sylvestris.

Methanogens have also been suggested to colonise tree stems (Zeikus and Ward 1974; Mukhin and Voronin 2011), and thus an undetectable small methanogen population could as well have inhabited the stems of the plants in our study. However, one reason why we did not detect methanogens in the plant material can be that the plants were relatively young and grown in the laboratory, while wood decay and methanogens have previously been found in stems of larger and older trees in the field (Berry and Beaton 1972; Zeikus and Ward 1974). In addition to transport of soil-derived $\mathrm{CH}_{4}$ and the possibility of having undetected methanogens within the plant material, the $\mathrm{CH}_{4}$ emitted from the shoots may be produced in situ within the plants in aerobic abiotic processes as suggested first by Keppler et al. (2006). Possible non-microbial origins of $\mathrm{CH}_{4}$ are leaf surface waxes, which have been detected to produce small amounts of $\mathrm{CH}_{4}$ even without exposure to UV radiation (Bruhn et al. 2014). Furthermore, saprotrophic fungi have also been identified as a source of $\mathrm{CH}_{4}$ under aerobic conditions (Lenhart et al. 2012). All the above mentioned mechanisms of $\mathrm{CH}_{4}$ production have assumed to be possibly common within plants.

Mature $P$. sylvestris trees have been demonstrated to emit small amounts of $\mathrm{CH}_{4}$ under field conditions (Machacova et al. 2016). The $\mathrm{CH}_{4}$ emissions from $P$. sylvestris stems and shoots in a boreal upland forest under field conditions were 0.31 and $3.1 \mathrm{nmol} \mathrm{h}^{-1} \mathrm{~m}^{-2}$ (medians), respectively (Machacova et al., 2016). If we convert these emissions to emissions per plant biomass, using the biomass of the needles calculated by Machacova et al. (2016) (with the function by Repola et al. (2007)) (4.4 kg), and the projected needle area (10-31 $\mathrm{m}^{2}$ per tree) (Machacova et al. 2016), the median flux from the needles under field condition is $0.017 \mathrm{nmol} \mathrm{h}^{-1} \mathrm{~g}^{-1}$.

Furthermore, if we calculate the total biomass of the branches including needles with an equation by Marklund (1988), by using the mean tree height and the mean stem diameter at breast height from Machacova et al. (2016), we get a larger total biomass (14 kg), and thus the median flux of $0.005 \mathrm{nmol} \mathrm{h}^{-1} \mathrm{~g}^{-1}$ from the branches. In the microcosm experiment, we measured $\mathrm{CH}_{4}$ fluxes between -2.7 and $3.3 \mathrm{nmol} \mathrm{h} \mathrm{h}^{-1} \mathrm{~g}^{-1}$ from the shoots of $P$. sylvestris. These fluxes cover the range observed in the field, but indicate much higher $\mathrm{CH}_{4}$ exchange rates. This is in line with Pangala et al. (2015), who demonstrated that young trees can have significantly greater stem $\mathrm{CH}_{4}$ 
emissions than mature trees. Part of the disparity results from upscaling of leaf-level $\mathrm{CH}_{4}$ emissions measured in the field to the whole-tree level, since both the biomass functions and the projected needle area include certain assumptions and thus they are only estimates, and also from the exclusion of the stems from the upscaling.

The net fluxes of the seedlings suggest that for most of the species the shoot emissions contribute substantially to the net $\mathrm{CH}_{4}$ exchange of these plant-soil systems (median contribution 91\%). Even though the net fluxes of the microcosms are not directly comparable to the natural conditions, as in our experimental setup the aboveand belowground compartments were separated, our results indicate that the ground vegetation is affecting the flux measured e.g. with the soil chambers and it should be taken into account in the experimental designs and result interpretations. The $\mathrm{CH}_{4}$ uptake by the soils in the microcosms was not necessarily as strong as it is in boreal forest soils naturally. At the site where the soil and the seeds for the microcosms were collected the net fluxes of the boreal forest floor have shown strong $\mathrm{CH}_{4}$ uptake based on the soil chamber measurements (Skiba et al. 2009; Machacova et al. 2016). In our experiment there was a relatively small amount of homogenised humus soil in each microcosm, and thus the disturbance and the lack of the natural soil horizons has presumably reduced the $\mathrm{CH}_{4}$ oxidation capacity in the soil. It is also noteworthy that the qPCR method does not give information about the activity of the detected methanotrophs.

The results of the flux measurements and the qPCR indicate that the plant roots increase the $\mathrm{CH}_{4}$ uptake by the methanotrophs in humus soils. The amounts of methanotrophs were mainly in line with the belowground fluxes: $V$. vitis-idaea soils had the most methanotrophs and the strongest average $\mathrm{CH}_{4}$ uptake, while the nonrooted soil had significantly less methanotrophs than the ericoid shrubs and seemed to be a small source of $\mathrm{CH}_{4}$. Praeg et al. (2016) also reported increased $\mathrm{CH}_{4}$ uptake by forest soils with tree roots compared to nonrooted forest soil. The differences between the rooted and non-rooted soils are related to the presence of roots, which are in interdependent relationship with the soil microbes via the root exudates (Broeckling et al. 2008). Alternatively, it is possible that the non-rooted soils were wetter than the rooted soils, as there was no plant evaporation, which may have created more suitable conditions for microbial $\mathrm{CH}_{4}$ production. The results also show some variation in both the belowground $\mathrm{CH}_{4}$ fluxes and the amount of methanotrophs between the species, $V$. vitis-idaea-rooted-soils indicating the strongest uptake. The effect of plant species and vegetation types on soil $\mathrm{CH}_{4}$ fluxes has also been shown by other studies (Praeg et al. 2016; Maier et al. 2017b). These differences can result from the different plant species effects on soil microbes, which may again result from the root exudates (Innes et al. 2004).

Upland forest soils typically favour methanotrophs specialized in oxidizing $\mathrm{CH}_{4}$ at atmospheric mixing ratio (Kolb 2009 and the references therein). As the primer mb661r did not work well with our samples and the primer A650r did, most of the methanotrophs in our samples likely belong to these so called high-affinity methanotrophs covered by the A650r and not by mb661r (Bourne et al. 2001). The numbers of the methanotrophs match the qPCR results from other forest soil studies (Kolb et al. 2005; Knief et al. 2006).

The same microcosms were used for soil characteristic (Adamczyk et al. 2016) and bacterial amount analyses (Timonen et al. 2016), and the relationships between these variables and the $\mathrm{CH}_{4}$ fluxes were also investigated. In our experiment, the soil pH was on average 4.5 in the non-rooted soils and 3.8 in the rooted soils (measured by Adamczyk et al. 2016). The $C$. vulgaris soils had the lowest pH, on average 3.7 , and within $C$. vulgaris soils the number of methanotrophs was the second highest. The non-rooted soils were less populated by the methanotrophs and had higher $\mathrm{pH}$ compared to the rooted soils. Also the total amounts of bacteria were lower in the non-rooted soils than the rooted soils (Timonen et al. 2016), indicating that roots support the bacteria in the soil and lower the soil $\mathrm{pH}$ to more suitable level for the bacteria. The lower $\mathrm{pH}$ is probably also more suitable for the boreal soil methanotrophs, even though the correlation analysis did not reveal any correlation between the soil pH and the fluxes. In addition, the heterotrophic bacterial diversity has shown to increase the 
$\mathrm{CH}_{4}$ oxidation (Ho et al. 2014), which is in line with our observation that the increase in the amount of bacteria in the roots increases the $\mathrm{CH}_{4}$ oxidation in the rooted soils.

The boreal forest soil methanotrophs are probably well adapted to low soil $\mathrm{N}$ content, because $\mathrm{N}$ is usually the limiting nutrient in these environments. This is supported by the findings that many methanotrophs are able to fix atmospheric $\mathrm{N}_{2}$ (Murrell and Dalton 1983; Auman et al. 2001; Dam et al. 2012). We found that an increase in $\mathrm{NH}_{4}$ concentration (measured by Adamczyk et al. 2016) increases the $\mathrm{CH}_{4}$ uptake in the rooted soils, which is in line with previous findings that in small amounts increasing available $\mathrm{N}$ stimulates $\mathrm{CH}_{4}$ uptake (Aronson and Helliker 2010), even though in larger amounts and during long time periods $\mathrm{N}$ fertilisation can inhibit $\mathrm{CH}_{4}$ oxidation (Steudler et al. 1989; Mosier et al. 1991; Gulledge et al. 2004). In case of the non-rooted soils the correlation between the $\mathrm{NH}_{4}$ concentration and the $\mathrm{CH}_{4}$ flux was not significant (Online Resource 1 ) probably due to less methanotrophs in the non-rooted soils, although the $\mathrm{NH}_{4}$ concentration was much higher in the non-rooted than in the rooted soils (Adamczyk et al. 2016). Overall the biogeochemical interactions between the soil $\mathrm{N}$ and $\mathrm{CH}_{4}$ fluxes are complex and require more research.

Humus soil of the boreal forests contains high concentrations of phenolic compounds (Smolander et al. 2012 and the references therein). Phenolic compounds have been shown to inhibit microbial activity, including methanogens (Olguin-Lora et al. 2003; Wang et al. 2015; Poirier et al. 2016), and inhibition of pure cultures of methanotrophs has also been reported (Amaral and Knowles 1997). Our results are somewhat conflicting showing that the more the water-soluble phenols in soil the more $\mathrm{CH}_{4}$ uptake in case of $P$. sylvestris, but an increase in the water-soluble phenols or the condensed tannins (measured by Adamczyk et al. 2016) in the soil cause an increase in the $\mathrm{CH}_{4}$ emissions from the shoots of all the studied species. Based on our results it is difficult to draw solid conclusions about the possible effects of phenols on $\mathrm{CH}_{4}$ fluxes.

The results of our experiment indicate that the aboveground parts of common boreal dwarf shrubs and $P$. sylvestris are able to emit $\mathrm{CH}_{4}$. As our objective was to assess the roles of above- and belowground parts to the $\mathrm{CH}_{4}$ fluxes, the results demonstrate that vegetation has an important and previously unrecognized role in the $\mathrm{CH}_{4}$ flux dynamics of boreal plant-soil systems. The aim of this study was also to evaluate the contribution of methanogens and methanotrophs to the $\mathrm{CH}_{4}$ exchange of common shrubs and $P$. sylvestris seedlings. The amount of methanotrophs in the rooted soil samples was mostly in line with the $\mathrm{CH}_{4}$ uptake of the belowground compartments of the microcosms indicating that the plant roots enhance the methanotrophic activity and thus the soil uptake of $\mathrm{CH}_{4}$. Although we did not detect methanogens in the shoots, roots or soil, we cannot exclude the possibility of methanogenic contribution to the net $\mathrm{CH}_{4}$ flux from the studied plants. Our findings from this microcosm experiment demonstrate that more research should be directed to understand the interactions between plants, soil, and the microbial community driving the $\mathrm{CH}_{4}$ exchange.

\section{Acknowledgements}

This study has been supported by the Emil Aaltonen Foundation, The Academy of Finland Centre of Excellence (project 272041), Academy of Finland Research Fellow projects (292699, 263858, 288494), InGOS, ICOS (271878), ICOS-Finland (281255) and ICOS-ERIC (281250) funded by the Academy of Finland.

Conflict of Interest: The authors declare that they have no conflict of interest.

\section{References}

Adamczyk B, Ahvenainen A, Sietiö O-M, Kanerva S, Kieloaho A-J, Smolander A, Kitunen V, Saranpää P, Laakso T, Straková P, Heinonsalo J (2016) The contribution of ericoid plants to soil nitrogen chemistry and organic matter decomposition in boreal forest soil. Soil Biol Biochem 103:394-404. doi: 10.1016/j.soilbio.2016.09.016

Amaral JA, Knowles R (1997) Inhibition of methane consumption in forest soils and pure cultures of methanotrophs by aqueous forest soil extracts. Soil Biol Biochem 29:1713-1720. doi: 10.1016/S0038-0717(97)00070-9

Andersen BL, Bidoglio G, Leip A, Rembges D (1998) A new method to study simultaneous methane oxidation and methane 
production in soils. Global Biogeochem Cycles 12:587-594. doi: 10.1029/98GB01975

Angel R, Claus P, Conrad R (2012) Methanogenic archaea are globally ubiquitous in aerated soils and become active under wet anoxic conditions. ISME J 6:847-862. doi: 10.1038/ismej.2011.141

Angel R, Matthies D, Conrad R (2011) Activation of Methanogenesis in Arid Biological Soil Crusts Despite the Presence of Oxygen. PLoS One 6:1-8. doi: 10.1371/journal.pone.0020453

Aronson EL, Helliker BR (2010) Methane flux in non-wetland soils in response to nitrogen addition: a meta-analysis. Ecology 91:3242-3251. doi: 10.1890/09-2185.1

Auman AJ, Speake CC, Lidstrom ME (2001) nifH Sequences and Nitrogen Fixation in Type I and Type II Methanotrophs. Appl Environ Microbiol 67:4009-4016. doi: 10.1128/AEM.67.9.4009

Berry FH, Beaton JA (1972) Decay in Oak in the Central Hardwood Region. USDA For Serv Res Pap NE-242:11 pp.

Bloom AA, Lee-Taylor J, Madronich S, Messenger DJ, Palmer PI, Reay DS, McLeod AR (2010) Global methane emission estimates from ultraviolet irradiation of terrestrial plant foliage. New Phytol 187:417-425. doi: 10.1111/j.14698137.2010.03259.x

Bomberg M, Münster U, Pumpanen J, Ilvesniemi H, Heinonsalo J (2011) Archaeal Communities in Boreal Forest Tree Rhizospheres Respond to Changing Soil Temperatures. Microb Ecol 62:205-217. doi: 10.1007/s00248-011-9837-4

Bourne DG, McDonald IR, Murrell JC (2001) Comparison of pmoA PCR Primer Sets as Tools for Investigating Methanotroph Diversity in Three Danish Soils. Appl Environ Microbiol 67:3802-3809. doi: 10.1128/AEM.67.9.3802-3809.2001

Broeckling CD, Broz AK, Bergelson J, Manter DK, Vivanco JM (2008) Root Exudates Regulate Soil Fungal Community Composition and Diversity. Appl Environ Microbiol 74:738-744. doi: 10.1128/AEM.02188-07

Bruhn D, Mikkelsen TN, Øbro J, Willats WGT, Ambus P (2009) Effects of temperature, ultraviolet radiation and pectin methyl esterase on aerobic methane release from plant material. Plant Biol 11:43-48. doi: 10.1111/j.14388677.2009.00202.x

Bruhn D, Mikkelsen TN, Rolsted MMM, Egsgaard H, Ambus P (2014) Leaf surface wax is a source of plant methane formation under UV radiation and in the presence of oxygen. Plant Biol 16:512-516. doi: 10.1111/plb.12137

Carmichael MJ, Bernhardt ES, Bräuer SL, Smith WK (2014) The role of vegetation in methane flux to the atmosphere: should vegetation be included as a distinct category in the global methane budget? Biogeochemistry 119:1-24. doi: 10.1007/s10533-014-9974-1

Cicerone RJ, Shetter JD (1981) Sources of Atmospheric Methane: Measurements in Rice Paddies and a Discussion. J Geophys Res 86:7203-7209. doi: 10.1029/JC086iC08p07203

Corley J (2003) Best practices in establishing detection and quantification limits for pesticide residues in foods. In: Lee PW, Aizawa H, Barefoot AC, Murphy JJ, Roberts T (eds) Handbook of Residue Analytical Methods for Agrochemicals. John Wiley \& Sons Ltd, Chichester, England, pp 59-75

Costello AM, Lidstrom ME (1999) Molecular Characterization of Functional and Phylogenetic Genes from Natural Populations of Methanotrophs in Lake Sediments. Appl Environ Microbiol 65:5066-5074.

Covey KR, Wood SA, Warren RJ, Lee X, Bradford MA (2012) Elevated methane concentrations in trees of an upland forest. Geophys Res Lett 39:L15705. doi: 10.1029/2012GL052361

Dam B, Dam S, Kube M, Reinhardt R, Liesack W (2012) Complete genome sequence of Methylocystis sp. strain SC2, an aerobic methanotroph with high-affinity methane oxidation potential. J Bacteriol 194:6008-6009. doi: 10.1128/JB.01446-12

Ding W, Cai Z, Tsuruta H (2005) Plant species effects on methane emissions from freshwater marshes. Atmos Environ 39:3199-3207. doi: 10.1016/j.atmosenv.2005.02.022

FAO/UNESCO (1990) FAO-UNESCO soil map of the world: revised legend. In: World Soil Resources Report. FAO, Rome,

Gauci V, Gowing DJG, Hornibrook ERC, Davis JM, Dise NB (2010) Woody stem methane emission in mature wetland alder trees. Atmos Environ 44:2157-2160. doi: 10.1016/j.atmosenv.2010.02.034

Goebel NL, Turk KA, Achilles KM, Paerl R, Hewson I, Morrison AE, Montoya JP, Edwards CA, Zehr JP (2010) Abundance and distribution of major groups of diazotrophic cyanobacteria and their potential contribution to $\mathrm{N}_{2}$ fixation in the tropical Atlantic Ocean. Environ Microbiol 12:3272-3289. doi: 10.1111/j.1462-2920.2010.02303.x

Gulledge J, Hrywna Y, Cavanaugh C, Steudler PA (2004) Effects of long-term nitrogen fertilization on the uptake kinetics of atmospheric methane in temperate forest soils. FEMS Microbiol Ecol 49:389-400. doi: 10.1016/j.femsec.2004.04.013

Hartmann DJ, Klein Tank AMG, Rusticucci M, et al (2013) Observations: Atmosphere and Surface. In: Stocker TF, Qin D, Plattner G-K, Tignor M, Allen SK, Boschung J, Nauels A, Xia Y, Bex V, Midgley PM (eds) Climate Change 2013: The 
Physical Science Basis. Contribution of Working Group I to the Fifth Assessment Report of the Intergovernmental Panel on Climate Change. Cambridge University Press, Cambridge, United Kingdom and New York, NY, USA, pp 159254

Ho A, de Roy K, Thas O, De Neve J, Hoefman S, Vandamme P, Heylen K, Boon N (2014) The more, the merrier: heterotroph richness stimulates methanotrophic activity. ISME J 8:1945-1948. doi: 10.1038/ismej.2014.74

Holmes AJ, Costello A, Lidstrom ME, Murrell JC (1995) Evidence that participate methane monooxygenase and ammonia monooxygenase may be evolutionarily related. FEMS Microbiol Lett 132:203-208. doi: 10.1111/j.15746968.1995.tb07834.x

Innes L, Hobbs PJ, Bardgett RD (2004) The impacts of individual plant species on rhizosphere microbial communities in soils of different fertility. Biol Fertil Soils 40:7-13. doi: 10.1007/s00374-004-0748-0

Joabsson A, Christensen TR, Wallén B (1999) Vascular plant controls on methane emissions from northern peatforming wetlands. Trends Ecol Evol 14:385-388. doi: 10.1016/S0169-5347(99)01649-3

Keppler F, Hamilton JTG, Braß M, Röckmann T (2006) Methane emissions from terrestrial plants under aerobic conditions. Nature 439:187-191. doi: 10.1038/nature04420

Kirschke S, Bousquet P, Ciais P, et al (2013) Three decades of global methane sources and sinks. Nat Geosci 6:813-823. doi: 10.1038/NGEO1955

Knief C, Kolb S, Bodelier PLE, Lipski A, Dunfield PF (2006) The active methanotrophic community in hydromorphic soils changes in response to changing methane concentration. Environ Microbiol 8:321-333. doi: 10.1111/j.14622920.2005.00898.x

Kolari P, Pumpanen J, Kulmala L, Ilvesniemi H, Nikinmaa E, Grönholm T, Hari P (2006) Forest floor vegetation plays an important role in photosynthetic production of boreal forests. For Ecol Manage 221:241-248. doi: 10.1016/j.foreco.2005.10.021

Kolb S (2009) The quest for atmospheric methane oxidizers in forest soils. Environ Microbiol Rep 1:336-346. doi: 10.1111/j.1758-2229.2009.00047.x

Kolb S, Knief C, Dunfield PF, Conrad R (2005) Abundance and activity of uncultured methanotrophic bacteria involved in the consumption of atmospheric methane in two forest soils. Environ Microbiol 7:1150-1161. doi: 10.1111/j.14622920.2005.00791.x

Kulmala L, Pumpanen J, Kolari P, Muukkonen P, Hari P, Vesala T (2011) Photosynthetic production of ground vegetation in different-aged Scots pine (Pinus sylvestris) forests. Can J For Res 41:2020-2030. doi: 10.1139/X11-121

Lenhart K, Bunge M, Ratering S, Neu TR, Schüttmann I, Greule M, Kammann C, Schnell S, Müller C, Zorn H, Keppler F (2012) Evidence for methane production by saprotrophic fungi. Nat Commun 3:1046. doi: 10.1038/ncomms2049

Lenhart K, Weber B, Elbert W, Steinkamp J, Clough T, Crutzen P, Pöschl U, Keppler F (2015) Nitrous oxide and methane emissions from cryptogamic covers. Glob Chang Biol 21:3889-3900. doi: 10.1111/gcb.12995

Livingston GP, Hutchinson GL (1995) Enclosure-based measurement of trace gas exchange: applications and sources of error. In: Matson PA, Lawton JH, Harriss RC, Likens GE (eds) Biogenic Trace Gases: Measuring Emissions from Soil and Water. Blackwell Science, Oxford, United Kingdom, pp 14-51

Lohila A, Aalto T, Aurela M, et al (2016) Large contribution of boreal upland forest soils to a catchment-scale $\mathrm{CH}_{4}$ balance in a wet year. Geophys Res Lett 43:2946-2953. doi: 10.1002/2016GL067718

Macdonald JA, Fowler D, Hargreaves KJ, Skiba U, Leith ID, Murray MB (1998) Methane Emission Rates from A Northern Wetland; Response to Temperature, Water Table and Transport. Atmos Environ 32:3219-3227. doi: 10.1016/S13522310(97)00464-0

Machacova K, Bäck J, Vanhatalo A, Halmeenmäki E, Kolari P, Mammarella I, Pumpanen J, Acosta M, Urban O, Pihlatie M (2016) Pinus sylvestris as a missing source of nitrous oxide and methane in boreal forest. Sci Rep 6:23410. doi: $10.1038 /$ srep23410

Maier M, Machacova K, Lang F, Svobodova K, Urban O (2017a) Combining soil and tree-stem flux measurements and soil gas profiles to understand $\mathrm{CH}_{4}$ pathways in Fagus sylvatica forests. J Plant Nutr Soil Sci. doi: 10.1002/jpln.201600405

Maier M, Paulus S, Nicolai C, Stutz KP, Nauer PA (2017b) Drivers of plot-scale variability of $\mathrm{CH}_{4}$ consumption in a wellaerated pine forest soil. Forests 8:1-16. doi: 10.3390/f8060193

Marklund LG (1988) Biomassafunktioner för tall, gran och björk i Sverige. Swedish University of Agricultural Sciences, Umeå, Sweden

Matson A, Pennock D, Bedard-Haughn A (2009) Methane and nitrous oxide emissions from mature forest stands in the boreal forest, Saskatchewan, Canada. For Ecol Manage 258:1073-1083. doi: 10.1016/j.foreco.2009.05.034 
Mosier A, Schimel D, Valentine D, Bronson K, Parton W (1991) Methane and nitrous oxide fluxes in native, fertilized and cultivated grasslands. Nature 350:330-332. doi: 10.1038/350330a0

Mukhin VA, Voronin PY (2011) Methane Emission from Living Tree Wood. Russ J Plant Physiol 58:344-350. doi: $10.1134 / \mathrm{S} 1021443711020117$

Murrell JC, Dalton H (1983) Nitrogen Fixation in Obligate Methanotrophs. J Gen Microbiol 129:3481-3486. doi: 10.1099/00221287-129-11-3481

Olguin-Lora P, Puig-Grajales L, Razo-Flores E (2003) Inhibition of the acetoclastic methanogenic activity by phenol and alkyl phenols. Environ Technol 24:999-1006. doi: 10.1080/09593330309385638

Pangala SR, Hornibrook ERC, Gowing DJ, Gauci V (2015) The contribution of trees to ecosystem methane emissions in a temperate forested wetland. Glob Chang Biol 21:2642-2654. doi: 10.1111/gcb.12891

Pangala SR, Moore S, Hornibrook ERC, Gauci V (2013) Trees are major conduits for methane egress from tropical forested wetlands. New Phytol 197:524-531. doi: 10.1111/nph.12031

Pihlatie MK, Christiansen JR, Aaltonen $\mathrm{H}$, et al (2013) Comparison of static chambers to measure $\mathrm{CH} 4$ emissions from soils. Agric For Meteorol 171-172:124-136. doi: 10.1016/j.agrformet.2012.11.008

Poirier S, Bize A, Bureau C, Bouchez T, Chapleur O (2016) Community shifts within anaerobic digestion microbiota facing phenol inhibition: Towards early warning microbial indicators? Water Res 100:296-305. doi: 10.1016/j.watres.2016.05.041

Praeg N, Wagner AO, Illmer P (2016) Plant species, temperature, and bedrock affect net methane flux out of grassland and forest soils. Plant Soil. doi: 10.1007/s11104-016-2993-z

Pumpanen JS, Heinonsalo J, Rasilo T, Hurme K-R, Ilvesniemi H (2009) Carbon balance and allocation of assimilated $\mathrm{CO}_{2}$ in Scots pine, Norway spruce, and Silver birch seedlings determined with gas exchange measurements and ${ }^{14} \mathrm{C}$ pulse labelling. Trees 23:611-621. doi: 10.1007/s00468-008-0306-8

Redding TE, Hannam KD, Quideau SA, Devito KJ (2005) Particle Density of Aspen, Spruce, and Pine Forest Floors in Alberta, Canada. Soil Sci Soc Am J 69:1503-1506. doi: 10.2136/sssaj2005.0018

Repola J, Ojansuu R, Kukkola M (2007) Biomass functions for Scots pine, Norway spruce and birch in Finland. Working Papers of the Finnish Forest Research Institute, Helsinki, Finland

Rice AL, Butenhoff CL, Shearer MJ, Teama D, Rosenstiel TN, Khalil MAK (2010) Emissions of anaerobically produced methane by trees. Geophys Res Lett 37:L03807. doi: 10.1029/2009GL041565

Rusch H, Rennenberg H (1998) Black alder (Alnus glutinosa (L.) Gaertn.) trees mediate methane and nitrous oxide emission from the soil to the atmosphere. Plant Soil 201:1-7. doi: 10.1023/A:1004331521059

Shoemaker JK, Keenan TF, Hollinger DY, Richardson AD (2014) Forest ecosystem changes from annual methane source to sink depending on late summer water balance. Geophys Res Lett 41:673-679. doi: 10.1002/2013GL058691

Sjögersten S, Wookey PA (2002) Spatio-temporal variability and environmental controls of methane fluxes at the foresttundra ecotone in the Fennoscandian mountains. Glob Chang Biol 8:885-894. doi: 10.1046/j.13652486.2002.00522.x

Skiba U, Drewer J, Tang YS, et al (2009) Biosphere-atmosphere exchange of reactive nitrogen and greenhouse gases at the NitroEurope core flux measurement sites: Measurement strategy and first data sets. Agric Ecosyst Environ 133:139149. doi: 10.1016/j.agee.2009.05.018

Smolander A, Kanerva S, Adamczyk B, Kitunen V (2012) Nitrogen transformations in boreal forest soils - does composition of plant secondary compounds give any explanations? Plant Soil 350:1-26. doi: 10.1007/s11104-011-0895-7

Steinberg LM, Regan JM (2008) Phylogenetic Comparison of the Methanogenic Communities from an Acidic, Oligotrophic Fen and an Anaerobic Digester Treating Municipal Wastewater Sludge. Appl Environ Microbiol 74:6663-6671. doi: 10.1128/AEM.00553-08

Steudler PA, Bowden RD, Melillo JM, Aber JD (1989) Influence of nitrogen fertilization on methane uptake in temperate forest soils. Nature 341:314-316. doi: 10.1038/341314a0

Sundqvist E, Crill P, Mlder M, Vestin P, Lindroth A (2012) Atmospheric methane removal by boreal plants. Geophys Res Lett 39:10-15. doi: 10.1029/2012GL053592

Terazawa K, Ishizuka S, Sakata T, Yamada K, Takahashi M (2007) Methane emissions from stems of Fraxinus mandshurica var. japonica trees in a floodplain forest. Soil Biol Biochem 39:2689-2692. doi: 10.1016/j.soilbio.2007.05.013

Timonen S, Sinkko H, Sun H, Sietiö O-M, Rinta-Kanto JM, Kiheri H, Heinonsalo J (2016) Ericoid Roots and Mycospheres Govern Plant-Specific Bacterial Communities in Boreal Forest Humus. Microb Ecol 1-15. doi: 10.1007/s00248-016$0922-6$ 
584 Topa MA, McLeod KW (1986) Aerenchyma and lenticel formation in pine seedlings: A possible avoidance mechanism to anaerobic growth conditions. Physiol Plant 68:540-550. doi: 10.1111/j.1399-3054.1986.tb03394.x

Vigano I, van Weelden H, Holzinger R, Keppler F, McLeod A, Röckmann T (2008) Effect of UV radiation and temperature on the emission of methane from plant biomass and structural components. Biogeosciences 5:937-947. doi: 10.5194/bg-5-937-2008

von Fischer JC, Hedin LO (2002) Separating methane production and consumption with a field-based isotope pool dilution technique. Global Biogeochem Cycles 16:8-1-8-13. doi: 10.1029/2001GB001448

Wang H, Richardson CJ, Ho M (2015) Dual controls on carbon loss during drought in peatlands. Nat Clim Chang 5:584-588. doi: $10.1038 /$ nclimate2643

Whiting GJ, Chanton JP (1992) Plant-dependent $\mathrm{CH}_{4}$ emission in a subarctic Canadian fen. Global Biogeochem Cycles 6:225-231. doi: 10.1029/92GB00710

Zeikus JG, Ward JC (1974) Methane formation in living trees: a microbial origin. Science 184:1181-1183. doi: 


\section{Plant and Soil}

\section{Above- and belowground fluxes of methane from boreal dwarf shrubs and Pinus sylvestris seedlings}

Table 1. The arithmetic means \pm standard errors of the means, medians, minimum and maximum of the $\mathrm{CH}_{4}$ fluxes in $\mathrm{nmol}$ $\mathrm{h}^{-1}$ and $\mathrm{nmol} \mathrm{h}^{-1} \mathrm{~g}^{-1}$ (DW of the total plant and/or soil mass), and the number of microcosms in each group. The statistics of the fluxes are given for the whole plant-soil system (net flux), and separately for the belowground (belowg.) and aboveground (aboveg.) compartments.

\begin{tabular}{|c|c|c|c|c|c|c|c|c|c|c|c|}
\hline & \multicolumn{5}{|c|}{$\mathrm{CH}_{4}$ Flux (nmol h-1) } & \multicolumn{5}{|c|}{$\mathrm{CH}_{4}$ Flux $\left(\mathrm{nmol} \mathrm{h}^{-1} \mathrm{~g}^{-1}\right)$} & \\
\hline & Mean & $\pm \mathrm{SE}$ & Median & Min & Max & Mean & $\pm \mathrm{SE}$ & Median & Min & Max & $\mathrm{n}$ \\
\hline $\begin{array}{l}\text { V. myrtillus } \\
\text { (net flux) }\end{array}$ & -0.14 & \pm 1.0 & -0.45 & -3.9 & 3.9 & -0.0029 & \pm 0.028 & -0.012 & -0.11 & 0.11 & 8 \\
\hline Belowg. & $-0.025^{a}$ & \pm 0.32 & 0 & -1.2 & 1.7 & $-0.0070^{a}$ & \pm 0.0091 & 0 & -0.035 & 0.049 & 8 \\
\hline Aboveg. & -0.16 & \pm 0.93 & 0 & -3.9 & 3.9 & -0.045 & \pm 0.61 & 0 & -3.2 & 3.0 & 8 \\
\hline $\begin{array}{l}\text { V. vitis-idaea } \\
\text { (net flux) }\end{array}$ & -1.7 & \pm 0.46 & -2.1 & -3.5 & 0.044 & -0.044 & \pm 0.012 & -0.052 & -0.086 & 0.0012 & 8 \\
\hline Belowg. & $-1.2^{b^{*}}$ & \pm 0.41 & -1.2 & -2.8 & 0 & $-0.035 b^{*}$ & \pm 0.012 & -0.036 & -0.081 & 0 & 8 \\
\hline Aboveg. & -0.46 & \pm 0.55 & 0 & -3.5 & 1.7 & -0.028 & \pm 0.15 & 0 & -0.71 & 0.83 & 8 \\
\hline $\begin{array}{l}\text { C. vulgaris } \\
\text { (net flux) }\end{array}$ & 3.2 & \pm 1.4 & 3.8 & -2.8 & 7.7 & 0.084 & \pm 0.036 & 0.10 & -0.078 & 0.20 & 8 \\
\hline Belowg. & $-0.051^{a}$ & \pm 0.24 & 0 & -1.5 & 0.75 & $-0.0015^{a}$ & \pm 0.0071 & 0 & -0.044 & 0.022 & 8 \\
\hline Aboveg. & 3.2 & \pm 1.5 & 4.2 & -3.6 & 7.3 & 1.1 & \pm 0.64 & 1.2 & -2.0 & 3.2 & 8 \\
\hline $\begin{array}{l}\text { P. sylvestris } \\
\text { (net flux) }\end{array}$ & 1.2 & \pm 1.5 & 0.78 & -7.2 & 6.3 & 0.032 & \pm 0.041 & 0.021 & -0.20 & 0.17 & 8 \\
\hline Belowg. & $-0.35^{a b}$ & \pm 0.16 & -0.19 & -1.2 & 0 & $-0.010 \mathrm{ab}$ & \pm 0.0045 & -0.0054 & -0.035 & 0 & 8 \\
\hline Aboveg. & 1.6 & \pm 1.5 & 0.97 & -6.6 & 6.7 & 0.54 & \pm 0.61 & 0.41 & -2.7 & 3.3 & 8 \\
\hline Non-rooted Soil & $0.59^{a}$ & \pm 0.37 & 0.44 & -1.1 & 3.5 & $0.019^{a}$ & \pm 0.013 & 0.011 & -0.039 & 0.12 & 11 \\
\hline
\end{tabular}

ab Means of the belowground fluxes denoted by a different letter are significantly different $(p<0.05)$

${ }^{*}$ Significant difference from zero $(p<0.05)$. 


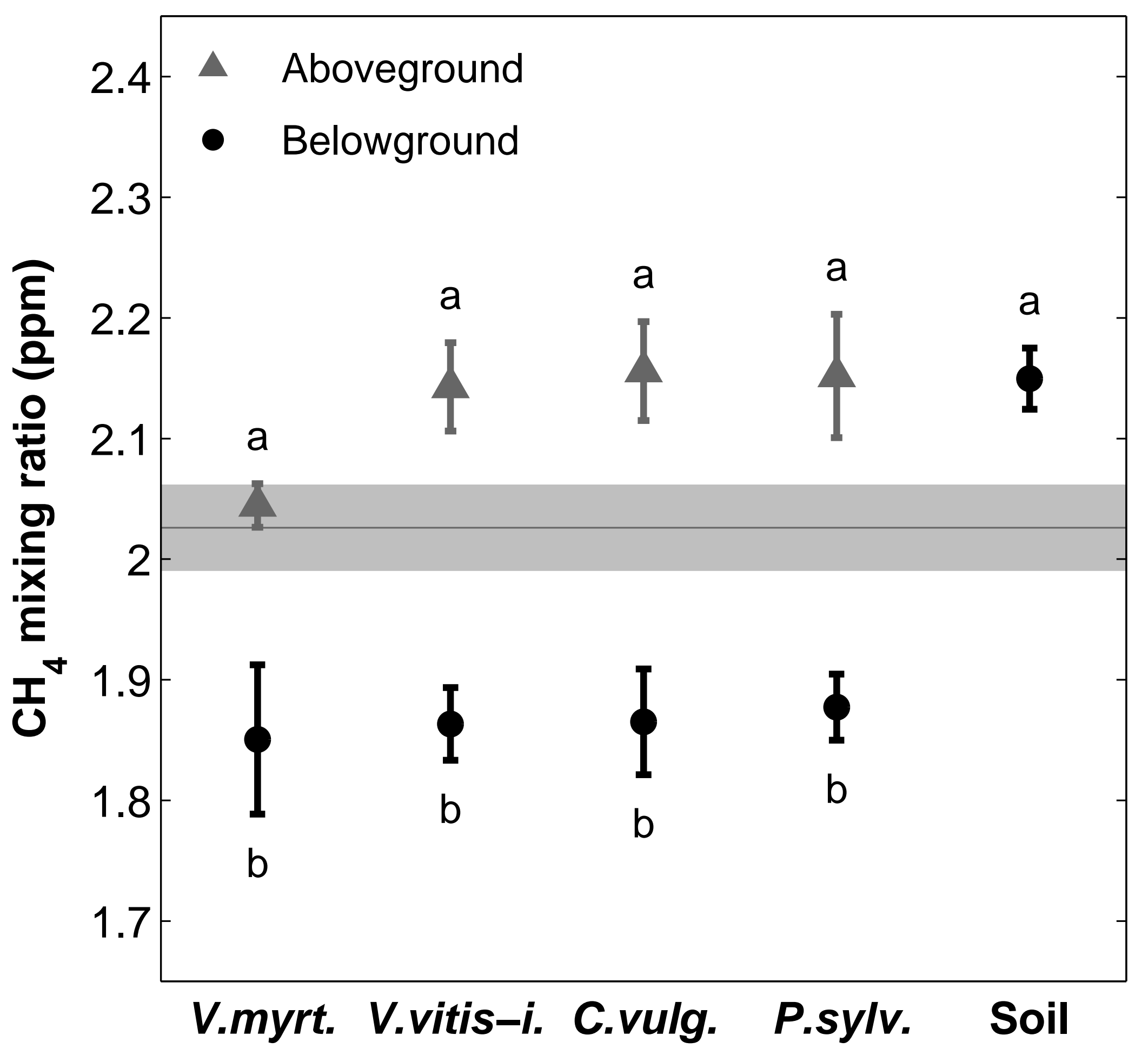




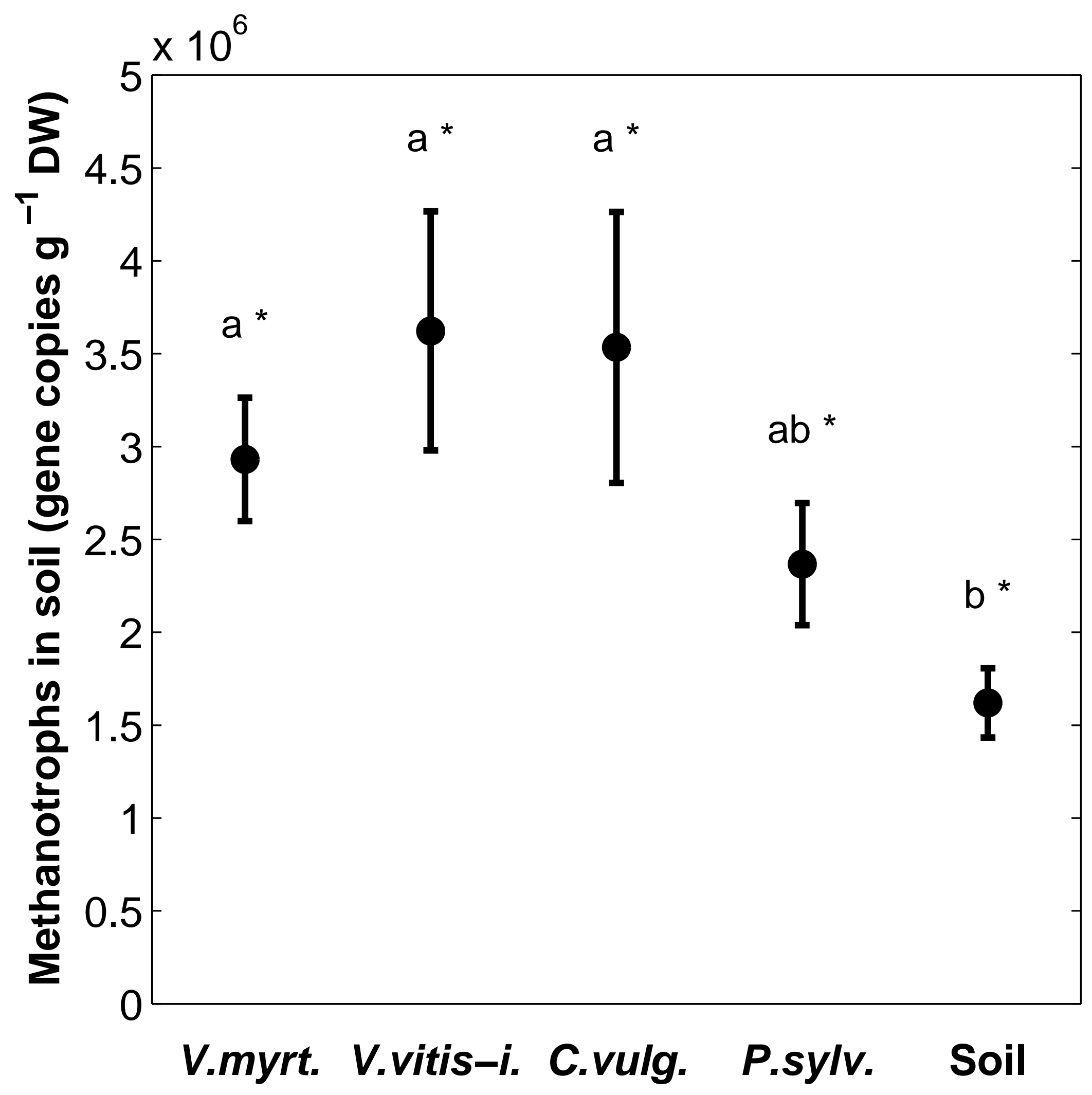

$a^{*} \quad a^{*}$

$a b$ *

b*

V.myrt. V.vitis-i. C.vulg. P.sylv. 
Electronic supplementary material

\section{Click here to access/download \\ Electronic supplementary material ESM_1_Halmeenmaki_etal.pdf}

